\title{
ANALYSIS OF SCIENCE PROCESS SKILLS OF CHEMICAL EDUCATION STUDENTS THROUGH SELF-PROJECT BASED LEARNING (SjBL) IN THE COVID-19 PANDEMIC ERA
}

\author{
Rusmini ${ }^{(D}$, Suyono ${ }^{(D}$, Rudiana Agustini iD \\ Universitas Negeri Surabaya (Indonesia) \\ rusmini@unesa.ac.id,suyono@unesa.ac.id,rudianaagustini@unesa.ac.id
}

Received April 2021

Accepted May 2021

\section{Abstract}

Research has been implemented related to the analysis of the students' science process skills through project-based learning in a Covid-19 pandemic era. The prohibition of face-to-face lectures causes hindered experimental activities to be conducted on campus. This condition encourages project-based learning to carry out extraction experiments independently (Self-Project Based Learning, SjBL). The method used in this study was the Pre-Experimental Design One-Shot Case Study involving 94 $4^{\text {th }}$ semester chemistry education students. The instruments used in this study were the science process skills assessment sheet, the activity observation sheet, and the students' response of the questionnaire. There were two highest skills showed by the students, namely, (1) determining tools and materials and (2) determining research variables indicators. The two skills were in excellent category. Skills to determine the work steps, and to make a data table including good categories. Quite good category was in the skills of making research objectives, making hypotheses, analyzing and drawing conclusions. Making a problem statement was in the bad category. In general, students' science process skills were in the good category. The activity of implementing student projects received an excellent category and students gave a positive response to project implementation during a pandemic. The results of this study contribute to science learning in the future. Efforts are needed to train science process skills to prospective chemistry teachers so that teachers who have good science process skills are produced.

Keywords - Covid-19 pandemic era, Science process skills, Self-Project Based Learning (SjBL).

\section{To cite this article:}

Rusmini, Suyono, \& Agustini, R. (2021). Analysis of science process skills of chemical education students through Self-project Based Learning (SjBL) in the Covid-19 pandemic era. Journal of Technology and Science Education, 11(2), 371-387. https://doi.org/10.3926/jotse.1288

\section{Introduction}

The attack of the corona virus pandemic at the end of 2019 and has been arriving in Indonesia in January 2020 had an impact on the learning process. Based on the Minister of Education and Culture Regulation (Permendikbud), students were no longer allowed to come to campus and lectures were conducted remotely (online) to prevent transmission of Covid-19 (Kompas, 2020; Kemendikbud 2020a). This condition had an impact on the constraints of practicum implementation in practical courses, including analytical 
chemistry 3 (the basics of chemical separation). According to Bagán, Sayós and García (2015) practicum activities had provide several opportunities to increase motivation, cooperation, self-regulation skills, communication and general skills. One of the subjects in this course was about extraction. Extraction was the process of separating an active substance from the mixture, which could be solid or liquid using the appropriate solvent (Tetti, 2014; Prayudo, Novian, Setyadi \& Antaresti, 2015). Thus, the extraction could be divided into liquid solid extraction and liquid-liquid extraction. Solid-liquid extraction was the process of separating a soluble substance from its insoluble solid in a suitable liquid solvent. Liquid-liquid extraction was the release of liquid from the mixture in a liquid form with a suitable solvent (Prayudo, et.al., 2015). There were many materials all around us that can be extracted, both solid-liquid extraction and liquid-liquid extraction. This case had been encouraging the project-based learning for the implementation of extraction practicum. The implementation of project-based learning was also in accordance with the Permendikbud No. 3 of 2020 in article 14 section 3 which states about learning methods for college students, one of them is project-based learning (Kemendikbud, 2020b).

Project-based learning was learning that actively able to build students' knowledge and experience trough the activity of making real projects to produce a contextual, challenging and interesting product to solve problems related to daily life (Craft \& Capraro, 2017; Asri, Setyosari, Hitipeuw \& Chusniyah, 2017; Na'imah, Supartono \& Wardani, 2015; Klein, 2019; Santyasa, Suastra \& Astawan, 2017). The advantage of the project-based learning model was students able to develop scientific characters such as being honest, responsible and able to communicate the knowledge that they had (Suparti 2015). Students learned independently without relied with their lecturer, they could have deeper understanding of the materials by associating with their real life (Iwamoto, Hargis \& Vuong, 2016; Requies, Agirre, Barrio \& Graells, 2018). Thus, it could increase motivation in learning because students could consider their knowledge to be more meaningful, relevant and useful to be applied to solve problems faced in daily life (Chiang \& Lee, 2016; Santyasa, Rapi \& Sara, 2020). Students were more actively involved in the teaching and learning process, students trained to make decisions and improve thinking skills, social skills and communication skills so that learning process could be more meaningful (McGrath, 2002; Solomon, 2003; Westwood, 2006; Craft \& Capraro, 2017; Chiang \& Lee, 2016; Suparti, 2015). The implementation of project-based learning went through five main steps: 1) determining the project theme, 2) determining the learning context, 3) planning activities, 4) processing activities, 5) implementing activities to complete the project (Santyasa, et.al. 2017).

Project assignments would be a good opportunity for students and their families to do things together in a Covid-19 pandemic era. Projects could also be a good opportunity for students to do things independently. That was sometimes needed by families during a long pandemic at home. By considering the average age of students who were 18 years old, according to Piaget, they entered the formal operational stage. At this stage the child already had the ability to use logic to solve problems, drew conclusions from the information that they got, and plan for their future. Thus, students considered able to design the project independently. This project-based learning was also a solution for practicum activities that were originally implemented in the laboratory into practicum activities at home by linking with real life.

Chasanah, Khoiri and Nuroso (2016) found that using a project-based learning model was more effective than conventional learning models in improving learning outcomes in the form of students' critical thinking and science process skills (SPS). Science process skills (SPS) were the ability to apply scientific methods to construct knowledge, understand, develop and discover science in order to solve problems and formulate results (Deta, Prakoso, Agustina, Fadillah, Lestari, Yantidewi et al., 2019; Ozgelen, 2012). Science process skills were divided into basic science process skills (basic SPS) and integrated science process skills (integrated SPS). Basic SPS consist of observing, using time or space relationships, inferring, measuring, communicating, classifying, and predicting. Integrated SPS included controlling variables, defining operationally, formulating hypotheses, interpreting data, experimenting, formulating models, and presenting information (Ozgelen, 2012; Nur, 2011; Kramer, Olson \& Walker, 2018).

Markawi (2013) states that science process skills (SPS) are skills possessed by scientists, comprehensive, systematic skills, analysis based on logical thinking, and methodology, involving physical and mental 
activities, in exploring, obtaining, understanding, and mastering science. Science process skills have a positive effect on increasing problem-solving abilities (Markawi, 2013), increasing scientific literacy (Handayani, Adisyahputra \& Insrayanti, 2018) the ability to make decisions in everyday life (Ozgelen, 2012), increasing students' creative thinking skills (Asy'ari \& Fitriani, 2017), improve critical thinking skills (Nugraha, Suyitno \& Susilaningsih, 2017). Science process skills will improve the quality of science learning, so that it will improve academic abilities as well as develop students' thinking abilities and potential (Winarti, Yuanita \& Nur, 2019). Given the great benefits of SPS, it is hoped that students will have good SPS abilities and further develop their abilities. This encourages research on the ability of SPS of students to carry out practicum independently, through project-based learning during Covid-19 pandemic era. Science process skills is most suitable to be implemented through practicum activities. Practicum is very important because it helps improve student's communication skills, solve problems in science, increase students interest in science, test hypotheses, understand observation and presentation of data (Shana \& Abulibdeh, 2020).

The implementation of this student project was carried out during structured assignment hours and students' independent training. Based on the Permendikbud No. 3 of 2020 in article 19 section 1 in each credit taken by students, there are 60 minutes in a credit every week for structured assignments and 60 minutes for independent activities. This project-based learning which was carried out independently called Self-Project Based Learning $(\mathrm{SjBL})$. The difference between $\mathrm{SjBL}$ and $\mathrm{PjBL}$ lied in the project implementation which SjBL implemented independently and $\mathrm{PjBL}$ implemented in a group. The project implementation steps still followed the steps of $\mathrm{PjBL}$. The selection of $\mathrm{SjBL}$ was in line with government regulations that applied rules of guarding distance and prohibitions on gathering together. By following the health protocol rules that have been established by the government, it is hoped that the Covid-19 outbreak will end soon. It was hoped that $\mathrm{SjBL}$ will greatly encouraged student independence. In addition, the use of structured assignment time outside of face-to-face hours could be used by students to develop themselves as well as possible. The assignment of tasks independently was also in accordance with the mandate of UU No. 20 of 2003 concerning the National Education System in article 3 which states that National Education functions to form independent human beings (DPR RI, 2003). Independent assignments encouraged more effective mastery of material. It helped the students to stimulate informative and professional interest, to develop creative activities and initiatives. Independent work had required students to do assignments by themselves and there was no direct contact with the lecturers, but there are some targets have to be completed (Abilkhamitkyzy, Aimukhambet \& Sarekenova, 2014). Giving structured assignments independently can increase motivation and learning achievement (Purnamasari \& Widodo 2018), increase the students' involvement, and increase their learning behavior (Hidayat, Rohaya, Nadine \& Ramadhan 2020).

Learning during this pandemic, where students do more assignments independently, was the reason why it has been interesting to observed their abilities and development especially in the students' science process skills. Science process skills was trained on students of the Chemistry Education study program as a provision for college students to become chemistry teachers. Chemistry was one of the subjects that required an understanding of science process skills. Students who had good science process skills will be able to teach their students better. Therefore, an analysis of the ability of students' science process skills was carried out through the implementation of SjBL on the extraction material.

\section{Method Research}

This study uses a quantitative approach with the Pre-Experimental Design One-Shot Case Study. In this study the sample group was given the same treatment and the results were observed. Treatment as the independent variable and outcome as the dependent variable (Sugiyono, 2018). This research was conducted in the Chemistry Education Study Program of Surabaya State of University (Unesa) in $4^{\text {th }}$ semester students totaling 94 students. The sampling technique used in this study was a total sampling technique. In this technique all members of the population are sampled (Darmaji, Kurniawan \& Irdianti 2019). A sample of 94 students, whose take analytical chemistry 3 course, was given the same treatment in 
the form of obtaining material extraction, explanation of project implementation, guidelines for project implementation and guidelines for science process skills. The research flow is shown in Figure 1.

Project implementation used structured assignment time and independent training so as not to interfere with face-to-face hours. Implementation of Self-Project Based Learning (SjBL) through five main steps, namely: 1) determining the project theme, 2) determining the learning context, 3) planning activities, 4) processing activities, 5) implementing activities to complete the project were all carried out by students independently. Students were allowed to be assisted by their families for the shooting and video editing process. More detailed student and lecturer activities during the implementation of SjBL can be seen in Table 1.

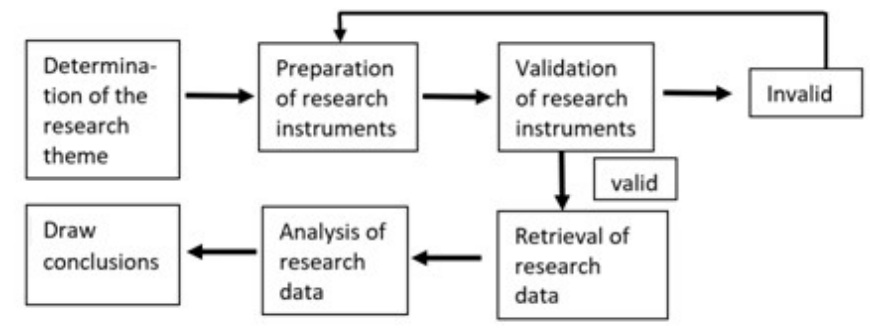

Figure 1. Research flow

\begin{tabular}{|c|c|c|c|c|}
\hline & SjBL Activities & Student Activities & Lecturer Activities & Note \\
\hline 1 & $\begin{array}{l}\text { Determine the } \\
\text { project theme }\end{array}$ & $\begin{array}{l}\text { The students decided what } \\
\text { substances would be extracted, what } \\
\text { types of extraction would be used, } \\
\text { and other matters related to } \\
\text { extraction. }\end{array}$ & $\begin{array}{l}\text { the lecturer determines the } \\
\text { general theme of the project, } \\
\text { about extraction }\end{array}$ & $\begin{array}{l}\text { Explored student } \\
\text { ideas }\end{array}$ \\
\hline 2 & $\begin{array}{l}\text { determines the } \\
\text { learning context }\end{array}$ & $\begin{array}{l}\text { students begin to understand the } \\
\text { assignment given, look for literature } \\
\text { and make observations on the } \\
\text { surrounding environment to observe } \\
\text { what materials can be extracted } \\
\text { simply }\end{array}$ & $\begin{array}{l}\text { lecturers receive discussions } \\
\text { and questions and answers } \\
\text { from students }\end{array}$ & $\begin{array}{l}\text { involves observing } \\
\text { and reading } \\
\text { literature activities }\end{array}$ \\
\hline 3 & stage of planning & $\begin{array}{l}\text { students were given the task of } \\
\text { making their own experimental } \\
\text { design, starting to determine the title, } \\
\text { formulating the problems, } \\
\text { determining experimental variables, } \\
\text { determining material and tools, and } \\
\text { preparing work steps }\end{array}$ & $\begin{array}{l}\text { lecturers receive discussions } \\
\text { and questions and answers } \\
\text { from students }\end{array}$ & $\begin{array}{l}\text { involves } \\
\text { independent work } \\
\text { activities and } \\
\text { creativity }\end{array}$ \\
\hline 4 & $\begin{array}{l}\text { At the processing } \\
\text { stage }\end{array}$ & $\begin{array}{l}\text { each student confirms that the design } \\
\text { being carried out is correct. At this } \\
\text { stage students begin to collect the } \\
\text { material and tools needed for the } \\
\text { extraction process so that there was } \\
\text { certainty that the extraction tools and } \\
\text { materials were available properly }\end{array}$ & $\begin{array}{l}\text { The lecturer confirms the } \\
\text { readiness of students for } \\
\text { independent practicum }\end{array}$ & $\begin{array}{l}\text { involves } \\
\text { independent work } \\
\text { activities and } \\
\text { creativity }\end{array}$ \\
\hline 5 & $\begin{array}{l}\text { The } \\
\text { implementation } \\
\text { of activities to } \\
\text { complete the } \\
\text { project }\end{array}$ & $\begin{array}{l}\text { students carry out the extraction } \\
\text { process independently and document } \\
\text { it in video form and make practicum } \\
\text { reports }\end{array}$ & $\begin{array}{l}\text { Lecturers watch student } \\
\text { videos to assess project } \\
\text { implementation } \\
\text { Lecturers assess practicum } \\
\text { reports to analyze students' } \\
\text { SPS abilities }\end{array}$ & $\begin{array}{l}\text { SjBL } \\
\text { implementation } \\
\text { data and } \\
\text { Student SPS data }\end{array}$ \\
\hline 6 & $\begin{array}{l}\text { Provided a } \\
\text { questionnaire on } \\
\text { SjBL responses }\end{array}$ & $\begin{array}{l}\text { Students fill out a response } \\
\text { questionnaire via google form }\end{array}$ & $\begin{array}{l}\text { The lecturer analyzes the } \\
\text { results of the student } \\
\text { questionnaire }\end{array}$ & $\begin{array}{l}\text { Students response } \\
\text { data }\end{array}$ \\
\hline
\end{tabular}

Table 1. activities of lecturers and students in SjBL 
The instrument was validated by 5 (five) validators who assess (1) the content, (2) the construction, and (3) the language of the instrument. Based on the validator judgment, the SPS assessment instrument is valid and feasible to use. The instrument used in this study was the science process skills assessment sheet through the collected reports. The project implementation observation sheet was used to observe the feasibility of the experiment through video collected and student response questionnaires via google form. The rubric for assessing science process skills for each category can be seen in Table 2 .

Science process skills that were focused on in this study are integrated science process skills which problem formulations, determine the objectives of the experiment, formulate hypotheses, determine experimental variables (manipulation, response and control variables), write down material tools, prepare work steps, conduct experiments and record in data tables of results and observations, analyze results and draw conclusions. The assessment of science process skills results is calculated based on the formula:

$$
\text { SPS Assessment Results }=\frac{\sum \text { scores obtained }}{\sum \text { maximum scores }} \times 100
$$

Science process skills assessment scores interpreted according to the categories in Table 3. Science process skills scores were also analyzed by SPSS 32 to determine whether or not there were differences in the three classes that were the research targets. The results of the analysis were then analyzed descriptively.

Project implementation observation data were analyzed using quantitative descriptive of the percentage of implementation. The percentage of project implementation was calculated using a formula.

$$
\% \text { implementation }=\frac{\sum \text { appear activity }}{\sum \text { total } \text { activities }} \times 100
$$

\begin{tabular}{|c|c|}
\hline SPS component & Assessment indicators \\
\hline $\begin{array}{l}\text { Determining experimental } \\
\text { objectives }\end{array}$ & $\begin{array}{l}\text { 1. In the form of statements } \\
\text { 2. Relating to word extraction } \\
\text { 3. There is manipulation variables } \\
\text { 4. There are response variables }\end{array}$ \\
\hline $\begin{array}{l}\text { Making problem } \\
\text { formulations }\end{array}$ & $\begin{array}{l}\text { 1. In the form of questions } \\
\text { 2. Relating to extraction } \\
\text { 3. Contains manipulation variables } \\
\text { 4. Containing response variables }\end{array}$ \\
\hline Formulating hypotheses & $\begin{array}{l}\text { 1. Relating to problem formulation } \\
\text { 2. predicts the answer while on the formulation of the problem } \\
\text { 3. in accordance with the theory of extraction } \\
\text { 4. is associated with the variable manipulation and response }\end{array}$ \\
\hline $\begin{array}{l}\text { Define variables } \\
\text { experiment }\end{array}$ & $\begin{array}{l}\text { 1. Dealing with the purpose of the experiment } \\
\text { 2. There are variable manipulation } \\
\text { 3. There are response variables } \\
\text { 4. There are control variables }\end{array}$ \\
\hline $\begin{array}{l}\text { Determine the tools and } \\
\text { materials for experiments }\end{array}$ & $\begin{array}{l}\text { 1. Dealing with the purpose of the experiment } \\
\text { 2. Writing tools experiment } \\
\text { 3. Writing materials -experimental } \\
\text { 4. materials Write down the tools or materials with the required quantity }\end{array}$ \\
\hline $\begin{array}{l}\text { Determine the } \\
\text { experimental }\end{array}$ & $\begin{array}{l}\text { 1. Instructions for the steps can be found Test / carried out } \\
\text { 2. Suitability of steps with manipulation variables } \\
\text { 3. suitability of steps with control variables } \\
\text { 4. Work steps are written in sequence and clearly }\end{array}$ \\
\hline $\begin{array}{l}\text { Make a table of } \\
\text { experimental data }\end{array}$ & $\begin{array}{l}\text { 1. Table form has columns and rows } \\
\text { 2. Corresponds to the objectives of the experiment } \\
\text { 3. Contains manipulation variables } \\
\text { 4. Contains response variables }\end{array}$ \\
\hline
\end{tabular}




\begin{tabular}{|l|l|}
\hline \multicolumn{1}{|c|}{ SPS component } & \multicolumn{1}{c|}{ Assessment indicators } \\
\hline \multirow{4}{*}{$\begin{array}{l}\text { Analyzes experimental } \\
\text { results }\end{array}$} & $\begin{array}{l}\text { 1. Relates to the objectives of the experiment } \\
\text { 2. Explains each stage in accordance with the theory of extraction / knowledge / } \\
\text { scientific understanding } \\
\text { 3. Explain all experimental data } \\
\text { 4. Explain the influence of manipulation variables on the response variable }\end{array}$ \\
\hline \multirow{3}{*}{ Make conclusions } & $\begin{array}{l}\text { 1. In accordance with the problem formulation } \\
\text { 2. Answering the relationship between manipulation variables to response variables } \\
\text { 3. Arranged based on the results of data analysis }\end{array}$ \\
& 4. Written in a brief statement sentence there is no further explanation in conclusion \\
\hline
\end{tabular}

\section{Guidelines Scoring:}

Score $0=$ students do not write down the answers

Score $1=$ students do in that section but do not meet all indicators

Score $2=$ students do in that section by covering 1 indicator

Score $3=$ students working in that section by including 2 indicators

Score $4=$ students working in that section covering 3 indicators

Score 5 = students working in that section covering 4 indicators

Table 2. Rubric for assessing student science process skills on the extraction project report

\begin{tabular}{|c|c|}
\hline Score scale & Category \\
\hline Score $\leq 40$ & Bad \\
\hline $40<$ score $\leq 55$ & Poor \\
\hline $55<$ score $\leq 65$ & Quite good \\
\hline $65<$ score $\leq 80$ & Good \\
\hline $80<$ score $\leq 100$ & Excellent \\
\hline
\end{tabular}

Table 3. SPS assessment criteria (Suyidno, Nur, Yuanita \& Salam 2020)

After obtaining the percentage of the analyzed score, then the percentage was categorized against the criteria as in Table 3. The questions in the response questionnaire are open questions that were analyzed descriptively qualitatively based on the results of student responses.

\section{Results and Discussion}

Self-Implementation Project Based Learning (SjBL) goes through five main steps, namely: 1) determining the project theme, 2) determining the learning context, 3) planning activities, 4) processing activities, 5) implementing activities to complete the project (Santyasa, et.al. 2017). In the first step, the lecturer provides project themes about extraction. The students decided what substances would be extracted, what types of extraction would be used, and other matters related to extraction. At this stage, students begin to explore project ideas about what to do. The second step determines the learning context in which students begin to understand the assignment given. Students begin to look for literature and make observations on the surrounding environment to observe what materials can be extracted simply. In the third stage of planning, students were given the task of making their own experimental design, starting to determine the title, formulating the problems, determining experimental variables, determining material and tools, and preparing work steps. At the processing stage, each student confirms that the design being carried out is correct. At this stage students begin to collect the material and tools needed for the extraction process so that there was certainty that the extraction tools and materials were available properly. The implementation stage of activities to complete the project was carried out by students by carrying out the extraction process independently and documenting in video form. Because learning in a pandemic Covid-19 situation, lecturers could not see directly the implementation of project activities, so making a project implementation video was chosen to observe student activities in implementing the project. For the final, students make a practicum report as a form of written presentation. The things written in the report include titles, problem formulations, experimental objectives, theoretical studies, hypotheses, manipulation, response and control variables, tools and materials, working steps, observational data tables, and conclusion. 


\subsection{Assessment Science Process Skills Student}

The assessment of science process skills was carried out on 4th semester chemistry education students. SjBL was conducted in May 2020. The data on the results of the science process skills assessment using SjBL are presented in Table 4.

Based on the data in Table 4, it shows that students' SPS abilities are in the bad to excellent category. The average score of the research question parameters from the three classes was in the bad category. Excellent category on tools \& material and variables parameters.

To determine whether or not there was a significant difference in SPS scores between groups A, B, and C, a statistical test was carried out with SPSS. Before that, the sample normality test was conducted first. The results of statistical tests are presented in Tables 5 and 6.

Data on the results of the normality test are presented in Table 5.

The basis of decision making for the Shapiro-Wilk normality test was if the significance value (Sig) $>0.05$ then the data was normally distributed, and if the significance value $(\mathrm{Sig})<0.05$ then the data was not normally distributed. Based on the results of the Shapiro-Wilk normality test above, the Sig. $<0.005$ in groups $\mathrm{A}, \mathrm{B}$, and $\mathrm{C}$. This indicates that the data for the three groups were not normally distributed. Then the Kruskal Wallis test was then performed as a Non-Parametric Statistical Test. The Kruskal Wallis test was used to make a comparison between two or more quantitative variables in the form of a ranking where the sample was an independent sample, and the assumption of normality was not fulfilled, the results were shown in Table 6.

\begin{tabular}{|l|r|r|r|r|r|r|r|c|}
\hline \multirow{2}{*}{ SPS Parameter } & \multicolumn{4}{|c|}{ Average Score } & \multicolumn{2}{c|}{ The Percentage of Score } & \multirow{2}{*}{ Category } \\
\cline { 2 - 9 } & Class A & Class B & Class C & Class A & Class B & Class C & Average & Cat \\
\hline Research questions & 2.29 & 2.72 & 0.00 & 45.71 & 54.44 & 0.00 & 33.39 & Bad \\
\hline Goal & 3.57 & 3.14 & 3.00 & 71.43 & 62.78 & 60.00 & 64.74 & Quite good \\
\hline Hypothesis & 3.14 & 3.72 & 2.17 & 62.86 & 74.44 & 43.48 & 60.26 & Quite good \\
\hline Tools \& Material & 4.86 & 5.00 & 4.78 & 97.14 & 100.00 & 95.65 & 97.60 & Excellent \\
\hline Variables & 4.46 & 4.14 & 5.00 & 89.14 & 82.78 & 100.00 & 90.64 & Excellent \\
\hline Work steps & 4.14 & 4.00 & 3.43 & 82.86 & 80.00 & 68.70 & 77.18 & Good \\
\hline Data table & 4.14 & 3.75 & 3.43 & 82.86 & 75.00 & 68.70 & 75.52 & Good \\
\hline Analysis & 3.29 & 3.14 & 3.00 & 65.71 & 62.78 & 60.00 & 62.83 & Quite good \\
\hline Conclusion & 3.29 & 2.86 & 3.04 & 65.71 & 57.22 & 60.87 & 61.27 & Quite good \\
\hline Average & 3.69 & 3.61 & 3.10 & 73.71 & 72.16 & 61.93 & 69.27 & Good \\
\hline Category & & & & Good & Good & Quite good & & \\
\hline
\end{tabular}

Table 4. The SPS average value data and categories based on the percentage of values

\begin{tabular}{|c|c|c|c|c|c|c|c|}
\hline & \multirow[b]{2}{*}{ Group } & \multicolumn{3}{|c|}{ Kolmogorov-Smirnova } & \multicolumn{3}{|c|}{ Shapiro-Wilk } \\
\hline & & Statistic & df & Sig. & Statistics & df & Sig. \\
\hline \multirow[t]{3}{*}{ Group Value } & Group A & .174 & 35 & .009 & .896 & 35 & .003 \\
\hline & Group B & .176 & 36 & .006 & .873 & 36 & .001 \\
\hline & Group C & .266 & 23 & .000 & .839 & 23 & .002 \\
\hline
\end{tabular}

${ }^{\text {a}}$ Lilliefors Significance Correction The

Table 5. Tests of Normality 


\begin{tabular}{|l|l|l|r|}
\hline \multicolumn{4}{|c|}{ Ranks } \\
\hline \multirow{3}{*}{ Group Value } & \multicolumn{1}{|c|}{ Group } & N & \multicolumn{1}{c|}{ Mean Rank } \\
\cline { 2 - 4 } & Group A & 35 & 53.10 \\
\cline { 2 - 4 } & Group B & 36 & 28.92 \\
\cline { 2 - 4 } & Group C & 23 & \\
\cline { 2 - 4 } & Total & 94 & \\
\hline
\end{tabular}

\begin{tabular}{|l|r|}
\hline \multicolumn{2}{|c|}{ Test Statistics } \\
\hline & \multicolumn{1}{|c|}{ Group Value $^{\text {a,b }}$} \\
\hline Chi-Square & 14,235 \\
\hline Df & 2 \\
\hline Asymp. Sig. & .001 \\
\hline
\end{tabular}

${ }^{a}$ Kruskal Wallis Test

${ }^{\mathrm{b}}$ Grouping Variable: Group

Table 6. data on the results of the Kruskal Wallis Test analysis

The mean rank value shows the average rank of each treatment. Based on the data in Table 6, it shows that group B gets the highest rank, then group A and the last rank is group C. To find out whether the overall difference in rank is statistically significant, the Kruskall Wallis Test is performed. The Kruskall Wallis test was used to measure statistically whether the difference in mean rank is significant or not. This data is used to make decisions by comparing the significant value (Asymp. Sig.) with a probability of 0.05 . First, we formulate the hypothesis and the next is decision making.

Formulation Research Hypothesis:

$H_{0}$ : There was no significant difference in SPS scores between groups $A, B$, and $C$

Ha: There was a significant difference in KPS scores between groups $A, B$, and $C$

in decision-making Kruskal Wallis

1. If the Asymp.Sig value $>0.05$, there was no significant difference or $\mathrm{H}_{0}$ is accepted.

2. If the Asymp.Sig value $<0.05$, there was a significant difference or $\mathrm{H}_{0}$ is rejected.

Decision Making and Interpretation of the Kruskal Wallis Test Output, based on the "Test Statistics" output above, the Asymp. Sig. value was $0.001<0.05$. It could be concluded that $\mathrm{H}_{0}$ was rejected and $\mathrm{Ha}$ was accepted, which means that there was a significant difference between the SPS scores between groups $\mathrm{A}, \mathrm{B}$, and $\mathrm{C}$.

Based on the data in Table 4 and statistical analysis in Table 5 and Table 6, it showed that students have worked on all the indicators of SPS, although with different results. The average value of science process skills was in the good category.

Based on these data, there are things that can be revealed in the student's SPS ability, such as:

1. The problem's formulation got the lowest assessment. There were $45.74 \%$ of students who did not write problem formulations. Of the $54.26 \%$ students who wrote the formulation of the problem got an average score of 33.39 in the bad category. All students who wrote the problem formulation were already in the form of questions, related to the goal but mostly not related to the manipulation variable and the response variable.

2. There were some students who wrote down the objectives of the experiment but it was not in accordance with the manipulation variables that were compiled, on average the objectives of the experiment that were written by the students were only extracting certain substances, for example extracting coconut oil. Meanwhile, the manipulation variables wrote down the temperature variations in the coconut oil extraction process. Another example, the objective of the experiment is written curcumin extraction from turmeric but in variable manipulation the size of the surface area is written by cutting and shredding, then writing the objective of the experiment is given a score of 3 . If the objective of the experiment includes the manipulation variables and the response, then it will be given a score of 5 , for example doing extraction with variations in 
extraction temperature on the extraction results, and also in accordance with the writing on the manipulation and response variables section.

3. The hypothesis has been written in the form of a statement. Most of the students did not associate the manipulation variables with the responses in their hypotheses. For example, students only wrote down the effect of temperature on coconut oil extraction. This causes the student's score to have not reached the maximum value on the hypothesis assessment and only reaches good criteria.

4. The determination of the experimental variables fell into excellent category. It was related to the writing of manipulation, control and response variables that were correct even though there were those that are not in accordance with the objectives of the experiment. There was no student who did not write down the experimental variables. It showed that students had understood well the role of experimental variables in an experiment.

5. Tools and materials could be identified very well by students. Students were able to estimate the need for tools and materials along with the amount needed.

6. The work steps correspond mostly to variable manipulation. There are also work steps in accordance with the manipulation and response variables but not in accordance with the objectives of the experiment. There are also those that are only in accordance with the objectives of the experiment and do not contain steps for manipulation, control and response variables.

7. The ability to present data in a data table, student scores between 2 and 5 . All data has been presented in a table consisting of rows and columns. Some data did not include manipulation variables. There was also a complete data table with manipulation and response variables.

8. The ability to perform analysis was still in the quite good category. The analytical activity was related to the theory but did not explain the relationship between the manipulation and response variables. There was no theory-related explanation relating to the manipulation and response variables. Only $5.32 \%$ got a score of 5 . A score of 4 was obtained by $26.6 \%$. While most got a score of 3 or enough $(46.81 \%)$ and there were still those who got a score of $2(21.28 \%)$. The ability to perform analysis was assessed by its suitability with the objectives of the experiment, explaining each step of the experiment in relation to the related theory, relating the data obtained from the experiment with the appropriate theory and explaining the effects of manipulation and response variables. Those who got a score of 2 only gave a description of the work step process.

9. The ability to make conclusions was still in the quite good category. Most of the conclusions made by students still contain descriptions and explanations. The conclusions were in accordance with the objectives of the experiment but did not include the results of treatment with the manipulation variable on the response variable.

The following is an example of student work in Science process skills, an example when making a problem formulation.

a) Writing the problem gets a score of $5(10.65 \%)$.

\subsection{Research Questions}

1. How do the extraction in pandan leaves using infundation method?

2. How does the comparison of leaf extract colour of pandan leaf compare based on the different in solute concentration?

Figure 2. examples of student answers who got a score of 5 in writing the problem

In this students' answers have compiled the research questions in the form of a question sentence, related to extraction, namely the extraction of pandan leaves using the infundation 
method, containing manipulation variables in the form of differences in solute concentrations and including response variables namely the comparison of the color of the pandan leaf extract.

b) Writing the problem formulation that got a score of $3(38.30 \%)$

\author{
1.2 Research Questions \\ How to separate the mixture through the extraction process on moringa leaves?
}

Figure 3. examples of student answers who got a score of 3 in writing the problem

The formulation of this problem is already in the question sentence and is related to extraction, namely Moringa leaf extraction, but it is not related to manipulation and response variables at all.

Examples of student work results in making experimental variables experimental:

a. Writing the experimental variables with a score of 5

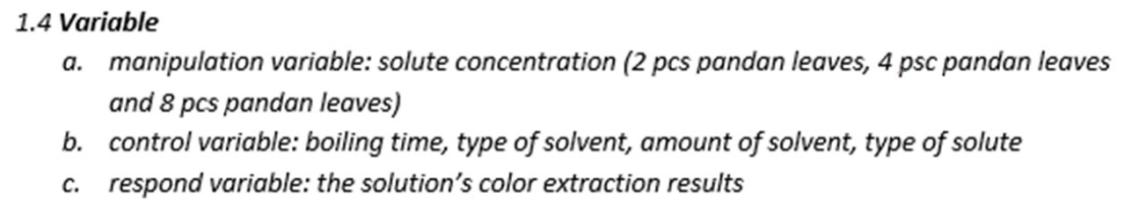

Figure 4. examples of student answers who got a score of 5 in writing variables

In determining the experimental variables most of the students have obtained a score of 5. The figure shows the suitability of the experimental variables with the experimental objectives

b. Writing the experimental variables with a score of 4

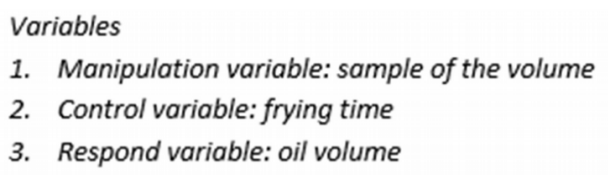

Figure 5. examples of student answers who got a score of 4 in writing variables

The variables are arranged correctly according to the objectives of the experiment but not complete. Like the control variable, only the frying time should be in addition to the frying time, there are other factors that must be controlled such as the tools and the size of the fire used.

c. Writing the experimental variable with a score of 3 .

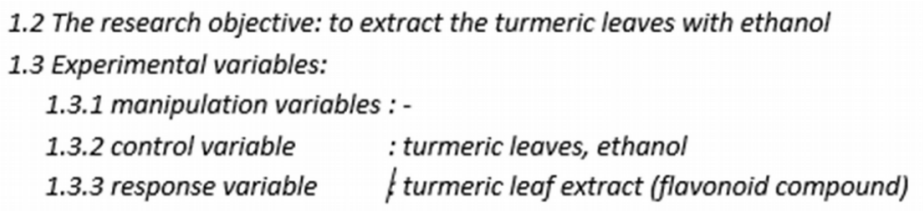

Figure 6. examples of student answers who got a score of 3 in writing variables 
Writing this variable was given a score of 3 . Although, in accordance with the objectives of the experiment, the manipulation variables were not written so that they only fulfill 2 assessment indicators only and get a score of 3 .

d. Writing experimental variables with a score of 2

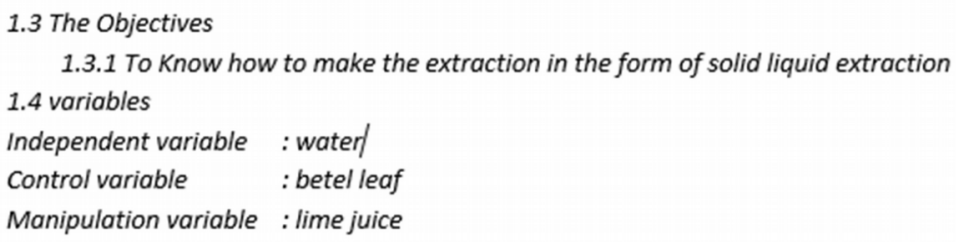

Figure 7. examples of student answers who got a score of 2 in writing variables

In writing this variable a score of 2 . Students write down the variables but they are not related to one another. The independent variable and manipulation are the same variable, but it is written twice. So that what is justified is the suitability of the betel leaf control variables with the experimental objectives.

Research on science process skills was also carried out by Elfeky, Masadeh \& Elbyaly (2019) and Darmaji et al. (2019). The results of research conducted by Elfeky et al. (2019) provided the results of the students' science process skills skills from the lowest were data interpretation, making operational definitions, making variables, conducting experiments, formulating hypotheses. Darmajis (2019) research results show that measuring skills are basic science process skills that get the lowest percentage of assessments. The highest percentage is the ability to make observational data tables. Whereas for integrated science process skills, classification skills obtained the lowest score and the skills in obtaining and processing data were the skills with the highest percentage scores.

Based on the data in Table 4, it is known that students' SPS abilities are in the bad to excellent category. Making research questions is the SPS activity with the lowest score and compiling the material tool is the SPS activity with the highest score. In this study, data analysis was included in the quite good category. Analyst activity is an activity that must focus on identifying assumptions, reasons, and claims and examining how students interact to form arguments (Dowd, Thompson, Schiff, \& Reynolds, 2018). According to Krathwohl (2002) analyzing is sorting the material into its constituent parts and recognizing the mutual relations between the parts, and the relationship between the parts and the overall structure or purpose. Operational verbs for analyzing include differentiating, organizing and attributing. In analyzing activities, conceptual knowledge is needed, so that analysis activities are not easy activities for students

If looked at the research results of Elfeky et al. (2019) the lowest SPS ability is data interpretation. Data interpretation related to analysis, focuses on determining meaning with precise information (Dowd et al., 2018). According to Gay, Mills and Airasian (2012) data interpretation is carried out by connecting the results with relevant theories, expanding the results of the analysis by asking questions regarding the relationship, the differences between the results of the analysis, the causes, the implications of the results of the previous analysis. The relationship between analysis and interpretation of data is interrelated. Based on the results of this study, it shows that the students' abilities in the cognitive level at level C4 according to Bloom's taxonomy are both still not good.

\subsection{Project-Based Experiment Implementation Observation Data Project}

Implementation project, in this case the experimental steps were observed based on videos that were collected by students. Observation data for the implementation of the experiment was presented in Table 7. The data in the Table 7 shows that students have been able to carry out experiments independently as part of the assigned project. The percentage of implementation showed an excellent category. Students' experiences in carrying out experiments would enter into their long-term memory so 
students will remember. This experience was important for the future of the students themselves. Independent student work increases mastery of material to be more effective, stimulates informative and professional interest, develops creative activities and initiatives, and encourages motivational growth (Abilkhamitkyzy et al., 2014; Purnamasari \& Widodo, 2018).

\begin{tabular}{|l|r|c|}
\hline \multicolumn{1}{|c|}{ Activity } & \multicolumn{1}{|c|}{$\begin{array}{c}\text { Percentage of } \\
\text { implementation }\end{array}$} & Category \\
\hline Provides tools and materials & 100 & Excellent \\
\hline Labels the container & 68.09 & Good \\
\hline Indicates manipulation variables & 89.36 & Excellent \\
\hline Carrying out experiments & 100 & Excellent \\
\hline Indicates a response variable & 100 & Excellent \\
\hline Average & 91.49 & Excellent \\
\hline
\end{tabular}

Table 7. Observation Data on Implementation of the Experiment

\subsection{Student Response to the Implementation of SjBL}

To find out student responses Then the student response questionnaire was filled out via Google Form. The questions were related to the benefits of the extraction practicum through project activities, the obstacles faced during the practicum, the ability to work together in implementing the project, and about the science process skills activities that were considered difficult and easy.

Regarding the benefits of the extraction practicum, they are asked to make their own projects, including students feeling challenged, more creative, increased curiosity, connecting chemistry with everyday life, increasing knowledge and insight, strengthening concepts, learning to solve problems. Student responses were consistent with results of previous studies (Santyasa et al, 2017; Yamin, Permanasari, Redjeki \& Sopandi 2017; Julian, 2017; Craft \& Capraro, 2017; Darmaji, et.al., 2019).

Constraints during the implementation of the practice, most of them answered no constraints. But someone replied that there was a slight problem. Another answer is that there was a problem with communication. Even though they are independent assignments, students are still allowed to have discussions with their friends. For those who have problems, this is because the project implementation is carried out over a distance which requires a good internet signal to support learning (Yudiawan, Sunarso, Suharmoko, Sari \& Ahmadi, 2021). The use of appropriate active learning methods in distance learning can reduce the anxiety to fail, can increase self-efficacy, promote in the positive emotions and increase learning outcomes (Jeong, González-Gómez, Cañada-Cañada, Gallego-Picó \& Bravo, 2019).

Regarding the question of the most difficult part of science process skills, most of them answer problem formulation, hypotheses and analysis. The easiest one: determine the material tool and create an experimental procedure. This was in accordance with the results of the project report assessment where the value of the determination of tools and materials received the highest value. Even though there were still difficulties in implementing science process skills, the more important thing was to try to do SPS independently as students who are preparing for their future independently and creatively.

The fifth question about the relationship between SjBL and concept understanding, students answered that by conducting their own experiments most students understood the extraction material better. This is in accordance with the adage of the Confucian philosopher if I hear I forget, I see I remember, I do I understand. The importance of students practicing their knowledge as reflected in the Edgar Dale Cone of Experience (Dale, 1969). That by conducting experiments $90 \%$ of students will remember what they say as they do a thing. This can be seen in Figure 8. The hope of learning outcome of students becoming experts in analysis, design, creation and evaluation can be realized. 


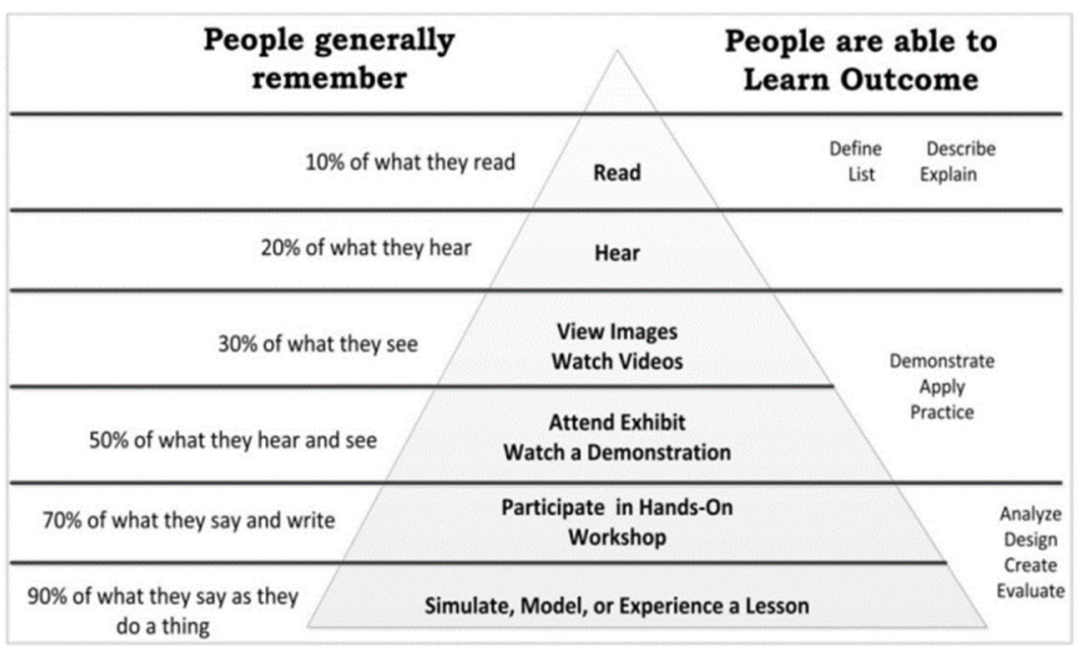

Figure 8. Edgar Dale Cone of Experience (Dale, 1969)

The implementation of Self-Project Based Learning is in accordance with Piaget's theory which states that student knowledge will develop when students face new experiences that force them to build and modify initial knowledge (Wrigley, 1998). Working on projects independently is a new experience for students. When facing this new experience students will be challenged to explore their personal abilities. This is also consistent with Vygotsky who stated that every individual when faced with new and challenging experiences he always tries to solve the problems raised by these experiences (Wrigley, 1998). Both of these expert statements are supported by constructivism theory which emphasizes the knowledge that students build themselves by using their existing experiences and cognitive structures (Wrigley, 1998).

\section{Conclusions}

Science process skills are very important in every science learning process. Science process skills are the basis for mastering other thinking skills. The results of this study indicate the low ability of students in science process skills although students gave a positive response to project implementation during a pandemic. An effort is needed to train science process skills to prospective chemistry teachers in order to produce teachers who have good science process skills. A good teacher will teach well to his students. The results of this study contribute to science learning in the future by science process skills. This research requires deeper application, especially related to independent project assignment $(\mathrm{SjBL})$. Because this is in line with the Indonesian National Education System Law which aims to make Indonesian people independent, it is also in line with the Minister of Education and Culture's Regulation regarding learning models in college which emphasize more on project implementation.

The weakness of this study is that it only measures integrated science process skills and does not measure students' critical thinking and creative thinking skills after implementing Self-Project Based Learning $(\mathrm{SjBL})$ as part of the 21 st century learning challenges. In this study also did not measure the initial ability of students to see the readiness of students to do their assignments independently through the application of Self-Project Based Learning (SjBL).

Further research on the effect of Self-Project Based Learning on critical thinking skills and creative thinking needs to be done. whether independent students are better able to master critical and creative thinking skills rather than carrying out projects in groups. The project-based learning model is a group and collaborative activity. However, in this study, project implementation was carried out individually due to the pandemic Covid-19 era. The results showed that individual project implementation had not been able to provide good results. Thus, it is still recommended that if you apply project-based learning, do it in groups and collaborations. If there is a pandemic like this, group project work can be done online. If you have to meet in person, you can do it in small groups and apply health protocols. Furthermore, it is also necessary to examine how student self-regulation with the application of this Self-Project Based Learning. 


\section{Declaration of Conflicting Interests}

The authors declared no potential conflicts of interest with respect to the research, authorship, and/or publication of this article.

\section{Funding}

The authors received no financial support for the research, authorship, and/or publication of this article

\section{References}

Abilkhamitkyzy, R., Aimukhambet, Z.A., \& Sarekenova, K.K. (2014). Organization of Independent Work of Students on Credit Technology. Procedia - Social and Behavioral Sciences, 143, 274-278.

https://doi.org/10.1016/j.sbspro.2014.07.403

Asri, D.N., Setyosari, P., Hitipeuw, I., \& Chusniyah, T. (2017). The influence of project-based learning strategy and self-regulated learning on academic procrastination of junior high school students' mathematics learning. American Journal of Educational Research, 5(1), 88-96.

https://doi.org/10.12691/education-5-1-14

Asy’ari, M., \& Fitriani, H., ( 2017) Literatur Reviu Keterampilan Proses Sains sebagai Dasar Pengembangan Keterampilan Berpikir Tingkat Tinggi. Prisma Sains: Jurnal Pengkajian Ilmu dan Pembelajaran Matematika dan IPA IKIP Mataram, 5(1), 1-17. https://doi.org/10.33394/j-ps.v5i1.1114

Bagán, H., Sayós, R, \& García, J.F., (2015). Skill Development in Experimental Courses. Journal of Technology and Science Education, 5(3), 169-183. https://doi.org/10.3926/jotse.158

Chasanah, A.R.U., Khoiri, N., \& Nuroso, H. (2016). Efektivitas Model Project Based Learning terhadap Keterampilan Proses Sains dan Kemampuan Berpikir Kreatif Siswa pada Pokok Bahasan Kalor Kelas X SMAN 1 Wonosegoro Tahun Pelajaran 2014/2015. Jurnal Penelitian Pembelajaran Fisika. 7(1), 19-24. https://doi.org/10.26877/jp2f.v7i1.1149

Chiang, C.L., \& Lee, H. (2016). The effect of project-based learning on learning motivation and problem-solving ability of vocational high school students. International Journal of Information and Education Technology, 6(9), 709-712. https://doi.org/10.7763/IJIET.2016.V6.779

Craft, A.M., \& Capraro, R.M. (2017). Science, technology, engineering, and mathematics project-based learning: Merging rigor and relevance to increase student engagement Electronic. International Journal of Education, Arts, and Science, 3(6), 140-158.

Dale, E. (1969). Audiovisual Methods in Teaching. New York: Dryden Press.

Darmaji, D., Kurniawan, D.A., \& Irdianti, I. (2019). Physics education students' science process skills. International Journal of Evaluation and Research in Education (IJERE), 8(2), 293-298. https://doi.org/10.11591/ijere.v8i2.16401

Deta, U.A., Prakoso, I., Agustina, P.Z.R., Fadillah, R.N., Lestari, N.A., Yantidewi et al. (2019). Science Process Skills Profile of Non-Science Undergraduate Student in Universitas Negeri Surabaya, IOP Conf. Series. Journal of Physics: Conf. Series, 1491(2020), 012067, 1-5, Seminar Nasional Fisika (SNF) Unesa. https://doi.org/10.1088/1742-6596/1491/1/012067

Dowd, J.E., Thompson, R.J., Schiff, L.A., \& Reynolds, J.A. (2018). Understanding the Complex Relationship between Critical Thinking and Science Reasoning among Undergraduate Thesis Writers. CBE-Life Sciences Education, 17(4), 1-10. https://doi.org/10.1187/cbe.17-03-0052

DPR RI (2003). Undang-Undang nomer 20 tahun 2003 tentang Sistem Pendidikan Nasional, Jakarta. 
Elfeky, A.I.M., Masadeh, T.S.Y., \& Elbyaly, M.Y.H. (2019). Advance Organizers in Flipped Classroom via E-learning Management System and the Promotion of Integrated Science Process Skills. Thinking Skills and Creativity, 35, 100622. https://doi.org/10.1016/j.tsc.2019.100622

Gay, L.R., Mills, G.E., \& Airasian, P. (2012). Educational Research Competencies for Analysis and Applications (10th ed.). London: Pearson Education.

Handayani, G., Adisyahputra, \& Indrayanti, R. (2018). Hubungan Keterampilan Proses Sains Terintegrasi dan Kemampuan Membaca Pemahaman Terhadap Literasi Sains Pada Mahasiswa Calon Guru Biologi. Biosfer: Jurnal Pendidikan Biologi (BIOSFERJPB), 11(1), 21-31.

Hidayat, D.R., Rohaya A., Nadine, F., \& Ramadhan H. (2020). Kemandirian Belajar Peserta Didik Dalam Pembelajaran Daring Pada Masa Pandemi Covid-19. Perspektif Ilmu Pendidikan, 34(2), 147-153. https://doi.org/10.21009/PIP.342.9

Iwamoto, D.H., Hargis, \& Vuong, K. (2016). The effect of project-based learning on student performance: An action research study. International Journal for the Scholarship of Technology Enhanced Learning, 1(1), 24-42.

Jeong, J.S., González-Gómez, D., Cañada-Cañada, F., Gallego-Picó, A., \& Bravo, J.C. (2019). Effects of active learning methodologies on the students' emotions, self-efficacy beliefs and learning outcomes in a science distance learning course. Journal of Technology and Science Education, 9(2), 217-227.

https://doi.org/10.3926/jotse.530

Julian, P.K. (2017). The effects of a project-based course on students' attitudes toward mathematics and students' achievement at a two-year college. The Mathematics Enthusiast, 14(1), 509-516.

Kemendikbud (2020a). Surat Edaran, nomor 3, tabun 2020, tentang Pencegaban COVID-19 pada Satuan Pendidikan. https://www.kemdikbud.go.id/main/blog/2020/03/surat-edaran-pencegahan-covid19-pada-satuan-pendidikan

Kemendikbud (2020b). Permendikbud, nomor 3, tahun 2020, tentang Standar Nasional Perguruan Tinggi. Jakarta: Kementerian Pendidikan dan Kebudayaan Republik Indonesia.

Klein, J.I. (2019). Project-Based Learning: Inspiring Middle School Students to Engage in Deep and Active Learning. New York: NYC Department of Education.

Kompas (2020). Mendikbud Perguruan Tinggi di Semua Zona Dilarang Kuliab Tatap Muka. https://www.kompas.com/edu/read/2020/06/16/103917571/mendikbud-perguruan-tinggi-di-semua-zonadilarang-kuliah-tatap-muka

Kramer, M., Olson, D. \& Walker, J.D. (2018). Design and Assessment of Online, Interactive Tutorials That Teach Science Process Skills. CBE-Life Sciences Education, 17(19), 1-11. https://doi.org/10.1187/cbe.17-06-0109

Krathwohl, D.R. (2002). A Revision of Bloom's Taxonomy: An Overview. Theory into Practice, 41(4), 212-218. https://doi.org/10.1207/s15430421tip4104_2

Markawi, N. (2013). Pengaruh Keterampilan Proses Sains, Penalaran, dan Pemecahan Masalah Terhadap Hasil Belajar Fisika. Jurnal Formatif, 3(1), 11-25. https://doi.org/10.30998/formatif.v3i1.109

McGrath, D. (2002). Getting started with project-based learning. Learning and Leading with Technology, 30(3), 42-50.

Na’imah, N.J., Supartono, \& Wardani S., (2015). Penerapan Pembelajaran Berbasis Proyek Berbantuan E-Learning Untuk Meningkatkan Hasil Belajar Siswa. Jurnal Inovasi Pendidikan Kimia, 9(2), 1566-1574. 
Nugraha, A.J., Suyitno, H., \& SUsilaningsih, E. (2017). Analisis Kemampuan Berpikir Kritis Ditinjau dari Keterampilan Proses Sains dan Motivasi Belajar melalui Model PBL. Journal of Primary Education, 6(1), $35-43$.

Nur, M. (2011). Modul keterampilan-keterampilan proses dan hakikat sains. Surabaya: PSMS Unesa.

Ozgelen, S. (2012). Students' Science Process Skills within a Cognitive Domain Framework. Eurasia Journal of Mathematics, Science \& Technology Education, 8(4), 283-292. https://doi.org/10.12973/eurasia.2012.846a

Prayudo, A.N., Novian, O., Setyadi, \& Antaresti (2015). Koefisien Transfer Massa Kurkumin Dari Temulawak. Jurnal Ilmiah Widya Tehnik, 14(1), 26-31.

Purnamasari, I.S., \& Widodo, S.A. (2018). Pengaruh Pemberian Tugas Terstruktur Secara Mandiri Terhadap Motivasi Dan Prestasi Belajar Matematika Siswa Kelas XI SMK PIRI 2 Yogyakarta. Prosiding Seminar Nasional Pendidikan Matematika Etnomatnesia. Universitas Sarjanawiyata Tamansiswa Yogyakarta (803-809).

Requies, J.M., Agirre, I., Barrio, V.L., \& Graells, M. (2018). Evolution of Project-Based Learning in Small Groups in Environmental Engineering Courses. Journal of Technology and Science Education, 8(1), 45-62. https://doi.org/10.3926/jotse.318

Santyasa, I.W., Suastra, I.W., \& Astawan, I.G. (2017). Project-based learning in achieving creative thinking and character for senior high school student in learning physics. Proceedings of the 2th Asian Education Symposium (415-423). https://doi.org/10.5220/0007305404150423

Santyasa, I.W., Rapi, N.K., \& Sara, I.W.W. (2020). Project Based Learning and Academic Procrastination of Students in Learning Physics. International Journal of Instruction, 13(1), 489-508.

https://doi.org/10.29333/iji.2020.13132a

Shana, Z.J., \& Abulibdeh, E.S. (2020). Science practical work and its impact on students' science achievement. Journal of Technology and Science Education, 10(2), 199-215. https://doi.org/10.3926/jotse.888

Solomon, G. (2003). Project-based learning: a primer, Technology and Learning, 23(6), 20-30.

Sugiyono (2018). Metode Penelitian Kuantitatif, Kualitatif dan R\&D. Bandung: Penerbit Alfabeta.

Suparti (2015). Project-based learning guided lesson study improve the achievement of learning outcomes on seminar accounting education course at department of accounting. IOSR Journal of Research \& Method in Education, 5(3), 5-11.

Suyidno, Nur, M., Yuanita, L., \& Salam, A. (2020). Creative Responsibility Based Learning Kreatif Pendidiknya, Dahsyat Peserta Didiknya. Banjarmasin: Lambung Mangkurat University Press.

Tetti, M. (2014). Ekstraksi, Pemisahan Senyawa, dan Identifikasi Senyawa Aktif. Jurnal Kesehatan, 7(2), 361-367.

Westwood, P. (2006). Teaching and learning difficulties: cross-curricular perspectives. Camberwell, Vic: ACER. Press.

Wrigley, H. (1998). Knowledge in action: The promise of project-based learning. Focus on Basics: Connecting Research and Practice, 2(D). National Centre for the Study of Adult Learning and Literacy. Available at: http://www.ncsall.net/index.html@id=384.htm

Yamin, Y., Permanasari, A., Redjeki, S., \& Sopandi, W. (2017). Application of Model Project Based Learning on Integrated Science in Water Pollution. Journal of Physics: Conf. Series, 895, 012153. https://doi.org/10.1088/1742-6596/895/1/012153

Yudiawan, A., Sunarso, B., Suharmoko, Sari, F., \& Ahmadi (2021). Successful online learning factors in COVID-19 era: Study of Islamic Higher Education in West Papua, Indonesia. International Journal of Evaluation and Research in Education (IJERE) 10(1), 193-201. https://doi.org/10.11591/ijere.v10i1.21036 
Winarti, A., Yuanita, L., \& Nur, M. (2019). The effectiveness of multipleintelligences based teaching strategy in enhancing the multiple intelligences and Science Process Skills of junior high school students. Journal of Technology and Science Education, 9(2), 122-135. https://doi.org/10.3926/jotse.404

Published by OmniaScience (www.omniascience.com)

Journal of Technology and Science Education, 2021 (www.jotse.org)

\section{(c) (i) $(\underset{\mathrm{BY}}{\mathrm{NC}}$}

Article's contents are provided on an Attribution-Non Commercial 4.0 Creative commons International License. Readers are allowed to copy, distribute and communicate article's contents, provided the author's and JOTSE journal's names are included. It must not be used for commercial purposes. To see the complete licence contents, please visit https://creativecommons.org/licenses/by-nc/4.0/. 